\title{
3D echo appearance of posterior leaflet prolapse due to chordae elongation
}

\author{
Umar Imran Hamid, ${ }^{1}$ Chris McConkey, ${ }^{2}$ Mehmood Jadoon, ${ }^{1}$ Harry Parissis, ${ }^{1}$ Alastair Graham ${ }^{1}$
}

${ }^{1}$ Department of Cardiothoracic Surgery, Royal Victoria Hospital, Belfast, UK;

2Department of Cardiothoracic Anaesthesia, Royal Victoria Hospital, Belfast, UK

Correspondence to Umar Imran Hamid, umar79@hotmail.com

\section{DESCRIPTION}

A 75-year-old male presented with exertional angina and breathlessness. The coronary angiogram showed disease affecting the left anterior descending and circumflex. Echocardiographic (echo) findings were predominantly P2 prolapse (video 1). On the three-dimensional (3D) echo there is obvious prolapse of the middle scallop of the posterior leaflet, no chordal rupture is seen; however, two rounded structure seen at the free edge of the posterior leaflet are indicative of chordal elongation (video 2). He underwent coronary artery bypass grafting $\times 2$ and mitral valve

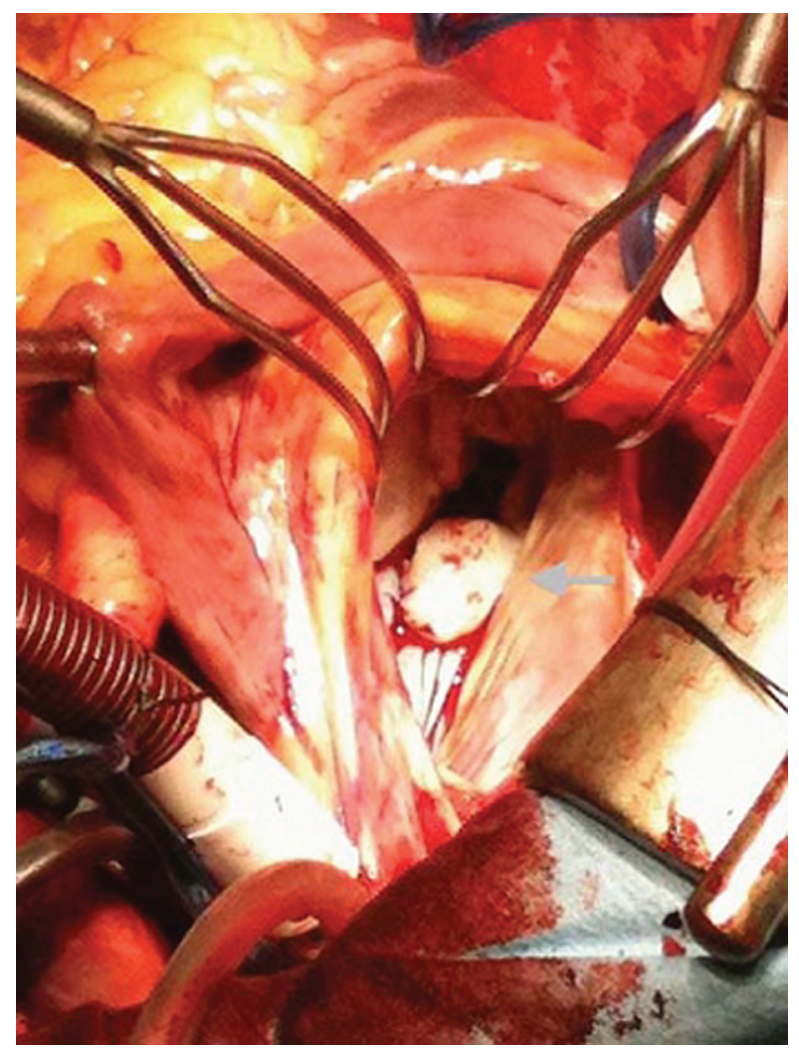

Figure 1 Intraoperative image of mitral valve (arrow indicating posterior leaflet). repair using Carpentier-Edwards physio II annuloplasty ring size $27 \mathrm{~mm}$ (Edward Life Sciences, Irvine, California, USA). Mitral valve repair involved quadrangular resection of the posterior leaflet (figure 1) (myxomatous), repaired with prolene 5/0 (ethicon). Intraoperative echo showed mild residual mitral regurgitation (MR). Postoperative period was complicated by chest sepsis requiring prolonged ventilation.

Video $12 D$ echocardiography showing failure of coaptation of mitral leaflet.

Video 2 3D echocardiography showing failure of coaptation of mitral leaflet.

$\mathrm{MR}$ is defined as an abnormal reversal of blood flow from the left ventricle to the left atrium caused by disruption in any part of the mitral valve apparatus, which comprises the mitral annulus, the leaflets, the chordae tendineae and the papillary muscles. The most common aetiologies of MR include mitral valve prolapse (MVP), rheumatic heart disease, infective endocarditis, annular calcification, cardiomyopathy and ischaemic heart disease. Acute and chronic MR affect approximately 5 in 10000 people.

Symptoms usually include dyspnoea, fatigue and orthopnoea resulting from impaired left ventricular function and pulmonary oedema.

3D echo using a transoesophageal approach is feasible and provides a detailed anatomic depiction of the mitral valve. This approach should be of value in the preoperative assessment of MVP, providing a complete visualisation of the valve before the intervention and possibly a better prediction of the feasibility of valve repair. ${ }^{1}$

The three basic principles to achieve an effective mitral valve repair include preservation of leaflet mobility, restore a large surface of coaptation and remodelling the annulus. $^{2}$

If surgery is undertaken before onset of symptoms and where left ventricular function is preserved, the life expectancy should be similar to that of the general population. ${ }^{3}$

The operative mortality for mitral valve surgery has steadily declined over the past decade, with the current mortality reported to the Society of Thoracic Surgery in the region of $1.5 \%$ for mitral valve repair and $5.5 \%$ for mitral valve replacement. 


\section{BMJ Case Reports}

Competing interests None.

Patient consent Obtained.

\section{REFERENCES}

1. Delabays A, Jeanrenaud X, Chassot PG, et al. Localization and quantification of mitral valve prolapse using three-dimensional echocardiography. Eur $\mathrm{J}$

Echocardiogr 2004;5:422-9.
2. Carpentier A, Deloche A, Dauptain J, et al. A new reconstructive operation for correction of mitral and tricuspid insufficiency. J Thorac Cardiovasc Surg 1971;61:1-13.

3. Mohty D, Orszulak TA, Schaff HV, et al. Very long-term survival and durability of mitral valve repair for mitral valve prolapse. Circulation 2001;104(12 Suppl 1):I1-7.

This pdf has been created automatically from the final edited text and images.

Copyright 2011 BMJ Publishing Group. All rights reserved. For permission to reuse any of this content visit

http://group.bmj.com/group/rights-licensing/permissions.

BMJ Case Report Fellows may re-use this article for personal use and teaching without any further permission.

Please cite this article as follows (you will need to access the article online to obtain the date of publication).

Imran Hamid U, McConkey C, Jadoon M, Parissis H, Graham A. 3D echo appearance of posterior leaflet prolapse due to chordae elongation. BMJ Case Reports 2011;10.1136/bcr.05.2011.4175, date of publication

Become a Fellow of BMJ Case Reports today and you can:

- Submit as many cases as you like

- Enjoy fast sympathetic peer review and rapid publication of accepted articles

- Access all the published articles

- Re-use any of the published material for personal use and teaching without further permission

For information on Institutional Fellowships contact consortiasales@bmjgroup.com

Visit casereports.bmj.com for more articles like this and to become a Fellow 